\title{
OS IMPACTOS CAUSADOS PELOS DECRETOS DA PREFEITURA DE BELO HORIZONTE NO LAZER DA POPULAÇÃO EM TEMPOS DE PANDEMIA
}

\author{
Recebido em: $10 / 08 / 2020$ \\ Aprovado em: 31/08/2020
}

Licença: @) $(1) \Theta$

\author{
Ana Cláudia Porfírio Couto ${ }^{1}$ \\ Fábio Henrique França Rezende ${ }^{2}$ \\ Universidade Federal de Minas Gerais (UFMG) \\ Belo Horizonte - MG - Brasil
}

Aládia Cristina Rodrigues Medina ${ }^{3}$

Pontifícia Universidade Católica de Minas Gerais (PUC-Minas)

Universidade Salgado de Oliveira (UNIVERSO)

Belo Horizonte - MG - Brasil

RESUMO: O lazer é direito constitucional e, em tempos de pandemia, o acesso a esse direito sofre consequências com o distanciamento social. Este estudo tem como objetivo analisar o impacto das medidas adotadas pela Prefeitura de Belo Horizonte $(\mathrm{PBH})$ durante a pandemia da Covid-19 nas práticas de lazer da população. Trata-se de uma pesquisa com dados secundários, na qual a investigação se deu através de uma revisão sistemática da literatura existente relacionando a pandemia da Covid-19, os Decretos da PBH referentes ao distanciamento social e quarentena previstos para a cidade. Considera-se que os equipamentos públicos de lazer e acesso aos mesmos sofreram impactos decorrentes da pandemia da Covid-19, modificando, portanto, as formas da população de vivenciar o lazer.

PALAVRAS-CHAVE: Decretos. Pandemia. Atividades de Lazer.

\section{THE IMPACTS IN LEISURE CAUSED BY THE DECREES OF BELO HORIZONTE'S CITY HALL DURING THE PANDEMIC}

\footnotetext{
${ }^{1}$ Professora na Escola de Educação Física Fisioterapia e Terapia Ocupacional da UFMG. Doutora em Ciência do Desporto - UP/Portugal; Pós-Doutorado Sociologia do Esporte e Lazer na Universidade Lusófona de Humanidades e Tecnologia/Portugal. Professora credenciada no Programa de Pós-graduação Interdisciplinar em estudos do Lazer. Líder do Grupo de Estudos em Sociologia Pedagogia do Esporte e Lazer - GESPEL.

${ }^{2}$ Bacharel em Educação Física pela Universidade Federal de Minas Gerais (UFMG), Brasil e aluno da continuidade de estudos do curso de Educação Física, Licenciatura, na UFMG. Membro do Grupo de Estudos em Sociologia e Pedagogia do Esporte e do Lazer (GESPEL/UFMG) e do Grupo de Estudos sobre Futebol e Torcidas (GEFuT/UFMG), Brasil.

${ }^{3}$ Doutora em Estudos do Lazer pela UFMG, Mestre em Educação pela Universidade de Itaúna, Especialista em Lazer e Recreação pela UFMG, Licenciatura pela em Educação Física pela UFMG, atualmente atua como professora nos cursos de formação em Educação Física na Pontifícia Universidade Católica MG e Universo.
} 
ABSTRACT: Leisure is a constitutional right and, in times of pandemic, access to that right suffers consequences with the social distance. This study aims to analyze the impact of the measures adopted by the Belo Horizonte City Hall (PBH) during the Covid-19 pandemic on the population's leisure practices. This is a survey with secondary data, in which the investigation took place through a systematic review of the existing literature relating the Covid-19 pandemic, the PBH Decrees regarding the social distance and quarantine planned for the city. Public leisure facilities and access to them are considered to have suffered impacts resulting from the Covid-19 pandemic, thus modifying the population's ways of experiencing leisure.

KEYWORDS: Decrees. Pandemic. Leisure Activities.

\section{Introdução}

O lazer faz parte de várias culturas e épocas, é um fenômeno da natureza humana, marcado, historicamente, pelo consumo e pela industrialização. A concepção de lazer teve estruturação em Marcelino (1998), que trata o lazer como cultura vivenciada no tempo disponível das obrigações, possuindo como principal traço o caráter desinteressado. Para Gomes (2014) o lazer passa a ser entendido como necessidade humana e dimensão da cultura, é parte da dinâmica da vida social e influenciado pela vida cotidiana.

O período de lazer é a mediação com o meio caracterizada pela livre escolha dos fazeres e pelo protagonismo. Podendo, neste contexto, ser vivenciado diante dos interesses pessoais e coletivos, no espaço urbano, nos equipamentos destinados ou não a este fim, sejam eles públicos ou privados, bem como nas redes sociais.

A fruição do lazer protagonizada pelas subjetividades individuais vivenciada nos espaços urbanos destinados a este fim se viu abruptamente interrompida a partir de Março de 2020 no Brasil, decorrente ao surgimento de um novo vírus ${ }^{4}$ (coronavírus) que

\footnotetext{
${ }^{4}$ Em dezembro de 2019, a China informou à Organização Mundial da Saúde (OMS) que um vírus até então desconhecido estava se espalhando pelo país. Para se evitar casos de xenofobia e não se confundir com outras doenças respiratórias ou similares, a OMS passou a chamar a doença de Covid -19 - Covid-19 significa Corona Virus Disease (Doença do Coronavírus), enquanto "19" se refere a 2019. Disponível em: https://portal.fiocruz.br/pergunta/por-que-doenca-causada-pelo-novo-virus-recebeu-o-nome-decovid-19. Acesso em: 25 maio 2020 às 16:00.
}

licere, Belo Horizonte, v.23, n.3, set/2020. 
rapidamente se espalhou pelo mundo, criando uma situação inusitada e desconhecida para a maioria da população, o chamado distanciamento social, que significa o afastamento das pessoas do convívio social, de modo a diminuir as aglomerações e assim controlar a propagação do vírus.

A medida do distanciamento social foi adotada após a OMS decretar o estado de pandemia por reconhecer que trata de um vírus novo com alto poder de transmissão, sem que a ciência tenha uma forma eficaz de prevenção, tratamento e controle, esse foi o único e eficaz método de controle da doença.

O controle da propagação e da contaminação rápida na população tem como finalidade prevenir um colapso nos sistemas de saúde, assim, os governos tomaram medidas em caráter de urgência para resguardar a população. Teve início então a campanha para que as pessoas ficassem em casa, além disso, outra medida para diminuir as aglomerações e contribuir com o distanciamento social foi o imediato fechamento dos estabelecimentos comerciais, clínicas, espaços de lazer, academias, suspensão de aulas nas instituições de ensino e atividades religiosas, somente os serviços ditos essenciais permaneceram em funcionamento.

Essas medidas de distanciamento social que também foram adotadas pela Prefeitura de Belo Horizonte, foram determinadas por meio de decretos, que mudaram a vida da população belorizontina, que passou a se exercitar, divertir e estudar, assistir a shows em casa e conviver pelas redes sociais. Dessa forma as vivências e experiências de lazer sofreram transformações passando a acontecer em reclusão e longe das aglomerações. As ações que foram efetivadas, a propagação de um vírus desconhecido, o distanciamento social e consequentemente uma vida diferente em todo o mundo, nos conduziu a um processo reflexivo de modo a questionarmos em que medida os decretos 
da PBH para o enfrentamento da Covid-19 impactaram as práticas de lazer dos cidadãos belohorizontinos.

Para dialogarmos e buscarmos responder a nosso questionamento, este estudo tem como objetivo geral analisar o impacto das medidas adotadas pela $\mathrm{PBH}$ durante a pandemia da Covid-19 nas práticas de lazer da população de Belo Horizonte. Este objetivo se desdobrou em dois objetivos específicos: analisar as medidas impostas pela PBH e relacionar os espaços de lazer e os consequentes impactos no lazer da população, a fim de estabelecer um diálogo diante da problemática do estudo. Acreditamos que, conhecer o impacto causado pelas ações que pontuamos nos possibilita discutir e compreender o "novo normal", como lidar com as novas relações que surgirão a partir desta pandemia. Dessa forma, pretende-se traduzir este impacto para o meio acadêmico e contribuir positivamente na análise e diálogos que possivelmente poderão ser desenvolvidos em um período pós pandemia, mas que carregará todas as diferenças que foram determinadas pelo distanciamento social.

\section{Procedimentos Metodológicos}

Este estudo trata de uma pesquisa com dados secundários, ou seja, a investigação se deu através de uma revisão sistemática da literatura existente relacionada à pandemia da Covid-19, dos Decretos da PBH referentes ao distanciamento social e quarentena previsto para a cidade decorrente da pandemia da Covid-19 e dos espaços de lazer públicos disponíveis nas regionais de $\mathrm{BH}$.

O procedimento da revisão sistemática foi realizado por meio de uma busca eletrônica no site da OMS, acerca dos conceitos relacionados à classificação das enfermidades e, por consequência, os motivos que levam a Covid-19 ser classificada como uma pandemia. Em seguida, buscamos informações na literatura, acerca do surgimento da 
Covid-19, de sua disseminação em um primeiro momento na China e na Ásia e em seguida em todo o mundo, das formas de contágio e de como prevenir e/ou desacelerar a transmissão em massa.

Em um momento posterior, realizamos a pesquisa no site da $\mathrm{PBH}$ dos Decretos que foram assinados pelo Prefeito de Belo Horizonte, Alexandre Kalil, desde o dia 17 de março de 2020 até o dia 26 de junho de 2020, com a finalidade de frear os avanços do novo coronavírus em Belo Horizonte. Esta temporalidade foi determinada por ser o $1^{\circ}$ decreto após a determinação da pandemia e o decreto que revogou toda a flexibilização da reabertura da cidade.

Esse momento do levantamento teórico teve dois objetivos: o primeiro foi entender os Decretos que a capital mineira vem publicando desde o início da quarentena, na semana de 17 de março e o segundo foi possibilitar traçar uma linha do tempo comparando os Decretos, o distanciamento social e as consequências desses para as práticas de lazer da população. Por fim, foi feito o levantamento dos espaços de lazer instalados nas nove regionais da PBH que são utilizados pelos cidadãos para a prática de lazer.

Os dados obtidos foram analisados e organizados diante dos temas propostos e mapeados de modo a subsidiarem a produção de um documento que se dedique a expor o impacto dos decretos nas práticas de lazer em Belo Horizonte.

\section{O Lazer}

Lazer é direito social garantido pela nossa Constituição. A Constituição Federal de 1988 foi um marco na legislação do nosso país nas diversas instâncias da vida: saúde, educação, assistência social, dentre outros, inclusive, o esporte e o lazer. Zingoni (2003) considera que "nas últimas décadas, o esporte e o lazer, como objeto de reivindicação 
popular ligada à ideia de cidadania, com a promulgação da Constituição Brasileira, em 1988, passaram a ser considerados direitos sociais de todos os cidadãos no nosso país" (p. 217). Dessa forma, o lazer é referenciado no artigo $6^{\circ}$ da Constituição Federal:

Título II

Dos Direitos e Garantias Fundamentais

Capítulo II

Dos Direitos Sociais

Art. $6^{\circ}$ São direitos sociais a educação, a saúde, a alimentação, o trabalho, a moradia, o transporte, o lazer, a segurança, a previdência social, a proteção à maternidade e à infância, a assistência aos desamparados, na forma desta Constituição.

Como importante direito social de todos os cidadãos brasileiros, vale ressaltar o entendimento sobre o que é lazer (ou o que estamos entendendo como lazer) que vem se ressignificando de acordo com cada momento histórico.

O conceito de lazer é permeado por conflitos, tensões, contradições e complexidades, possibilitando a coexistência de lógicas distintas (GOMES, 2018), de tempos/espaços diferenciados. Para os sociólogos, em geral, o lazer representa o tempo disponível após a liberação das atividades de trabalho e das atividades habituais, enquanto na visão dos etnólogos ${ }^{5}$, o lazer é uma manifestação cultural que sempre existiu em nossa sociedade (GOMES, 2003).

Nesse sentido, o lazer dialoga com o contexto e reflete as ambiguidades e contradições nele presentes. Por um lado, o lazer pode contribuir para a manutenção do status quo, reforçar estereótipos e valores excludentes, consumistas e alienantes, na

\footnotetext{
5 De acordo com GOMES (2003), a etnologia é um ramo da Antropologia que estuda a cultura das sociedades tradicionais, relacionando-se com a Antropologia cultural que se dedica à discussão das características culturais do homem que envolve os costumes, crenças, comportamentos, organização social etc. "Chamada diversamente de etnociência, análise componencial ou antropologia cognitiva, esse pensamento afirma que a cultura é composta de estruturas psicológicas por meio das quais os indivíduos ou grupos de indivíduos guiam seu comportamento. A cultura de uma sociedade consiste no que quer que seja que alguém tem que saber ou acreditar a fim de agir de um afirma aceitas pelos seus membros" (GEERTZ, 2008, p. 8).
} 
perspectiva da lógica dominante, ou, por outro lado, reveste-se de possibilidades para colaborar com a constituição de uma nova sociedade, mais justa, humanizada, inclusiva, digna e comprometida com os princípios democráticos. Tais considerações revelam que, em nossa sociedade, o lazer é um fenômeno dinâmico, complexo, dialético, permeado de conflitos, tensões e ambiguidades (GOMES, 2003, 2004, 2014). Trata-se de um fenômeno cultural, social e historicamente construído.

Portanto, para além da complexidade da trama social na qual o lazer é embutido, foi no final do século XIX que o lazer passou a ser compreendido como um tempo subtraído do tempo de trabalho, excedente, residual, o tempo livre! Um tempo, inclusive, propício para fugir da rotina, compensar frustrações, descansar ou buscar divertimento. Por esta razão, o fator tempo é relevante para a ocorrência do lazer na modernidade urbana e industrial (GOMES, 2003). Dessa forma, envolve dois fundamentos importantes: tempo e atitude. O primeiro está relacionado ao tempo liberado do trabalho ou "tempo livre", além da liberdade das questões sociais. Enquanto a atitude é caracterizada como o tipo de relação que se verifica entre o sujeito e a experiência (MARCELLINO, 2006).

A perspectiva da liberdade de escolha do que fazer no tempo livre das obrigações salienta a necessidade de problematizar as representações das categorias tempo/espaço. Enfatiza-se a questão tempo e negligencia-se a questão espaço, sendo que o olhar deve ser associado ao tempo e ao espaço de fruição do lazer. Dessa forma, extrapola-se a noção de tempo fora do trabalho ou das obrigações escolares e familiares, pois a vida não é feita de momentos e de situações estanques (GOMES, 2018). É interessante observar como as práticas que integram a cultura de cada povo podem assumir múltiplos significados, "ao serem concretizadas em um determinado tempo/espaço social, ao dialogarem com um determinado contexto e, também, ao assumirem um papel peculiar para os sujeitos, para os grupos sociais, para as instituições e para a sociedade" (GOMES, 2018, p 35). 
Dessa forma, é no município "que a população vive e é nele que toda e qualquer forma de política, de ações governamentais, interferem diretamente" (RODRIGUES, 2007, p.13) na vida das pessoas. Essas ações estão mais próximas do usuário quando elas se concretizam no âmbito das cidades.

Belo Horizonte, é uma cidade que possui diversos pontos de lazer para a sua população. Ao todo são 79 parques distribuídos pelas nove regionais da cidade, sendo que todas as regionais possuem ao menos um parque. Estes parques têm como opções de lazer equipamentos de ginástica, pistas de corrida, áreas verdes, campos de futebol, quadras poliesportivas, brinquedos (gratuitos e tarifados) e ciclovias. De acordo com o levantamento feito pelo Conselho Regional de Educação Física de Minas Gerais (CREF6/MG), a cidade possui 174 academias registradas em 2014 e a expectativa era que até 2019, esse número alcançasse 300 unidades. Essas academias de musculação são ambientes utilizados pelas pessoas para a manutenção e melhora da forma física, mas também são entendidas por muitos como um ambiente de socialização e de lazer.

Continuando, também é reconhecida pelo seu potencial para a prática de esportes de aventura. Em 2006 foi criado o Circuito BH 360 . Esse projeto conseguiu organizar mais de 50 eventos em Belo Horizonte e em cidades vizinhas que estão a um raio de 100 Km da capital mineira. Podemos citar como atividades planejadas: wakeboard; ciclismo; supermoto; escalada; corrida de aventura; Trekking de regularidade; vôo livre; motocross; rally; canoagem e paintball.

Não podemos esquecer dois dos marcos principais de Belo Horizonte: o Estádio Governador Magalhães Pinto (Mineirão) e a Lagoa da Pampulha. O Mineirão foi inaugurado em 5 de setembro de 1965, sendo o principal palco futebolístico de Minas Gerais, recebendo grandes jogos e até mesmo algumas partidas da Copa do Mundo de 2014. Com a sua reforma para a Copa, o Mineirão passou a ter uma esplanada em que 
nos dias que o estádio não está recebendo jogos, pode receber shows e a visitação do público para atividades de lazer, como andar de bicicleta, skate, patins, realização de caminhadas e corridas. Já a Lagoa da Pampulha possui 18 Km de extensão, é reconhecida como cenário para diversas atividades como: caminhada, ciclismo, competições internacionais, queima de fogos e contemplação da natureza. Nos últimos anos, vem ocorrendo a revitalização da lagoa que passou pelo processo de desassoreamento e, atualmente, o espelho d'água está em fase de limpeza, o que significa a preservação de um dos mais conhecidos cartões postais do Brasil que se tornou patrimônio cultural da humanidade em $2016^{6}$.

Como destacado, Belo Horizonte é uma cidade que tem uma oferta muito ampla de espaços, em todo seu espaço para a prática de lazer, quer seja nos locais previamente definidos para as práticas de lazer ou mesmo os espaços que são resignificados pelos sujeitos.

\section{Os Decretos da PBH e a Covid-19}

A história da humanidade se viu marcada por doenças que atingiram sociedades em diferentes épocas e localidades, deixando profundas marcas (SILVA, 2020). Como exemplos dessas pandemias, podemos citar: a Varíola, que surgiu na Índia, durante a Antiguidade e chegou ao Império Romano no século II d.C. causando milhares de mortes; assim como um tipo do vírus influenza, causador de gripes, que surgiu em 1580 na Ásia e se espalhou para a África, Europa e América do Norte ${ }^{7}$. As mutações do vírus influenza foram responsáveis pela Gripe Espanhola em 1918, doença que surgiu nos Estados Unidos e se espalhou durante a Primeira Guerra Mundial com o envio das tropas

\footnotetext{
6 Disponível em: http://g1.globo.com/jornal-nacional/noticia/2016/07/pampulha-se-torna-patrimoniocultural-da-humanidade.html. Acesso em: 21 jul. 2020 às 19:30.

7 Disponível em: https://www.historiadomundo.com.br/curiosidades/cinco-doencas-que-marcaram-ahistoria-da-humanidade.htm. Acesso em: 01 jul. 2020 às 10:45.
}

licere, Belo Horizonte, v.23, n.3, set/2020. 
americanas para diferentes localidades do planeta. Estima-se que 50 milhões de pessoas tenham morrido na pandemia da gripe espanhola, mais do que os 17 milhões de vítimas, entre civis e militares, da Primeira Guerra Mundial. Em 2009 houve a propagação do vírus H1N1, causador da gripe Suína ${ }^{8}$.

Dessa forma, percebe-se que a disseminação de pandemias $^{9}$, no decorrer da história, foi catalisadora de transformações significativas no modo de vida da sociedade e incentivou o desenvolvimento científico, com a finalidade de combatê-las e garantir a sobrevivência da espécie humana.

A Covid- $19^{10}$ foi detectada pela primeira vez na cidade chinesa de Wuhan e se espalhou em um espaço de poucos meses para mais de 100 países no mundo, recebendo por isso, a denominação de pandemia pela OMS. De acordo, com a reportagem da $\mathrm{UOL}^{11}$ um grupo de 14 pesquisadores internacionais estudaram 781 sequências genéticas de coronavírus que foram encontrados em morcegos na China. A suspeita encontrada nesse estudo, é que um grupo de morcegos do gênero Rhinolophus (Morcego - Ferradura) tenha sido o principal responsável pela evolução da pandemia, visto que 96,2\% do sequenciamento dessa espécie é idêntica ao Sars-Cov-2, nome oficial do vírus da Covid19. É interessante dizer, que a pandemia é chamada de novo coronavírus, pois em 2002 já existiu uma primeira mutação do vírus de morcegos em seres humanos, que ficou conhecido como Sars-Cov- 1.

\footnotetext{
${ }^{8}$ Disponível em: https://noticias.uol.com.br/ultimas-noticias/bbc/2020/03/11/o-que-e-pandemia-e-o-quemuda-apos-declaracao-da-oms-sobre-o-novo-coronavirus.htm. Acesso em: 01 jul. 2020 às 11:01.

9 A acadêmica especialista em doenças infecciosas da Escola de Higiene e Medicina Tropical de Londres, Rosaling Eggo, explicou para a BBC, a diferença entre endemia, epidemia e pandemia. Para ela, a infecção endêmica está presente em uma zona de maneira permanente, em todos os momentos durante anos. Já a epidemia, é caracterizada por um aumento de casos seguidos de um ponto máximo e, depois, uma diminuição. Por último, a pandemia é uma epidemia que ocorre em todo o mundo mais ou menos ao mesmo tempo. (Buscar a referência da OMS,a acadêmica deve apenas ser concordando com o oficial)

${ }^{10}$ De acordo, com https://jornal.usp.br/artigos/covid-tem-genero/. Acesso em: 11 jul. 2020 às 15:58.

11 Disponível em: https://noticias.uol.com.br/ultimas-noticias/agencia-estado/2020/06/05/estudo-apontarelacao-de-962-entre-novo-coronavirus-e-morcego-ferradura.htm. Acesso em: 03 jul. 2020 às 11:22.
} 
A pandemia da Covid-19 já havia sido retratada de maneira indireta, em um capítulo do livro Spillover - Animal Infections and the Next Pandemic, do escritor norte - americano especialista em ciência e natureza David Quammen. Nessa obra publicada em 2012 e ainda, sem tradução para o português, o autor retrata como vírus e bactérias infectam animais selvagens ou domésticos e conseguem migrar para a espécie humana, se tornando um problema global, causando doenças e mortes. O termo inglês Spillover que pode ser traduzido para o português como transbordamento, vem da ideia de um vírus ou bactéria conseguir se deslocar de uma espécie hospedeira para outras, justamente o que ocorreu com o agente causador da Covid-19.

A ideia de David Quammen é oriunda da teoria do transbordamento que é aceita pela comunidade científica, pois ao longo da história são encontrados exemplos de zoonoses que viraram doenças humanas. Um marco inicial é o vírus Hendra, que passou de cavalos para humanos em meados da década de 90 na Austrália, mas que possui a sua origem em morcegos. Há também a gripe, que é originada em aves e pode fazer um estágio em outras espécies, como o porco ${ }^{12}$. Além disso, de acordo com o virologista Paulo Eduardo Brandão, expert em coronavírus e professor da Universidade de São Paulo (USP), há duas hipóteses mais documentadas para o surgimento da Covid-19. Na primeira, o vírus foi entrando em contato aos poucos com a espécie humana e criando estratégias para fazer o salto. Na segunda, ele teria vindo mais "pronto" de um morcego e feito a transmissão interespécie de modo mais acelerado ${ }^{13}$.

Rapidamente a Covid-19 se alastrou pelo mundo, chegando a 114 países, levando a Organização Mundial da Saúde (OMS) a decretar o estado de pandemia causada pelo

\footnotetext{
${ }^{12}$ Disponível em: https://saude.abril.com.br/medicina/coronavirus-pandemia-zoonose/. Acesso em: 01 jul. 2020 às 11:22.

${ }^{13}$ Disponível em: https://saude.abril.com.br/medicina/coronavirus-pandemia-zoonose/. Acesso em: 01 jul. 2020 às 11:26.
}

licere, Belo Horizonte, v.23, n.3, set/2020. 
novo coronavírus em 10 março de 2020. A escalada do surto originado na cidade chinesa de Wuhan e a velocidade com que o novo coronavírus se espalhou pelo mundo, não é exatamente surpreendente em um mundo globalizado. No Brasil a $1^{\mathrm{a}}$ notificação de caso da Covid-19 ocorreu em fevereiro na cidade de São Paulo. Em Belo Horizonte a $1^{\text {a }}$ notificação de caso ocorreu em 15 de março de 2020.

De acordo, com o diretor-executivo do programa de emergências da OMS, Michael Ryan, uma pandemia não se caracteriza pela gravidade da doença que ela causa, mas sim, pelo fator geográfico, quando todas as pessoas no mundo correm risco $^{14}$. O novo coronavírus apresenta justamente esse potencial de transmissão comentado, mas parece ser menos letal do que aqueles por trás de outras duas epidemias nas últimas duas décadas. Ainda, a OMS estima que 3,4\% dos pacientes morrem por causa da Covid-19, a doença causada por este vírus.

Desde que a OMS classificou a Covid-19 como uma pandemia, a Prefeitura de Belo Horizonte assume a Situação de Emergência em Saúde Pública declarada por meio do Decreto $\mathrm{n}^{\circ}$ 17.297, de 17 de março de 2020, com o objetivo de prevenir e conter o avanço do novo coronavírus na capital mineira através da ampliação do distanciamento social. Dessa forma, foram analisados dezessete Decretos que o Prefeito de Belo Horizonte, Alexandre Kalil, assinou desde a data citada acima.

\section{Decreto $n^{0}$ 17.297, de 17 de Março de 2020}

"Declara situação anormal, caracterizada como Situação de Emergência em Saúde Pública, no Município de Belo Horizonte em razão da necessidade de ações para conter a propagação de infecção viral, bem como de preservar a saúde da população contra o Coronavírus - COVID-19” (BELO HORIZONTE, 17 de março de 2020).

\footnotetext{
${ }^{14}$ Disponível em: https://noticias.uol.com.br/ultimas-noticias/bbc/2020/03/11/o-que-e-pandemia-e-o-quemuda-apos-declaracao-da-oms-sobre-o-novo-coronavirus.htm. Acesso em: 01 jul. 2020 às 11:10.
} 


\section{Decreto n⿳ 17.298, de 17 de Março de 2020}

"Dispõe sobre medidas temporárias de prevenção ao contágio e de enfrentamento e contingenciamento, no âmbito do Poder Executivo, da epidemia de doença infecciosa viral respiratória causada pelo agente Coronavírus - COVID-19” (BELO HORIZONTE, 17 de março de 2020).

Decreto $n^{0}$ 17.304, de 18 de Março de 2020 - Revogado pelo Decreto $n^{\circ} 17.328$, de 8/4/2020 (Art. 11)

“Determina a suspensão temporária dos Alvarás de Localização e Funcionamento e autorizações emitidos para realização de atividades com potencial de aglomeração de pessoas para enfrentamento da Situação de Emergência Pública causada pelo agente Coronavírus - COVID - 19” (BELO HORIZONTE, 19 de março de 2020).

\section{Decreto $n^{0} 17.308$, de 19 de Março de 2020}

"Dispõe sobre medidas excepcionais de diferimento tributário para a redução dos impactos sobre a atividade econômica do Município causados pelas ações de contenção da pandemia ocasionada pelo COVID - 19" (BELO HORIZONTE, 19 de março de 2020).

\section{Decreto $n^{0}$ 17.309, de 19 de Março de 2020}

“Altera o Decreto no 11.375 , de 2 de julho de 2003, que dispõe sobre o funcionamento do Programa Bolsa-Moradia no Município de Belo Horizonte e dá outras providências" (BELO HORIZONTE, 19 de março de 2020).

\section{Decreto no 17.313, de 21 de Março de 2020}

"Determina condições temporárias para realização de atividades de teleatendimento, central de telemarketing e call center para enfrentamento da Situação de Emergência em Saúde Pública causada pelo agente Coronavírus - COVID-19” (BELO HORIZONTE, 21 de março de 2020). 


\section{Decreto $n^{\circ}$ 17.319, de $1^{\circ}$ de Abril de 2020}

“Dispõe sobre a prorrogação do prazo de validade das Certidões Negativas de Débitos e Certidões Positivas com Efeitos de Negativas de Débitos relativos a créditos municipais, em decorrência da pandemia relacionada ao Coronavírus - COVID-19', (BELO HORIZONTE, 21 de março de 2020).

\section{Decreto n 17.326, de 6 de Abril de 2020}

"Determina a proibição da circulação no território do Município de Belo Horizonte de transporte público coletivo oriundo de municípios que interromperem as medidas de isolamento social" (BELO HORIZONTE, 6 de abril de 2020).

\section{Decreto $n^{\circ}$ 17.328, de 8 de Abril de 2020}

"Suspende por tempo indeterminado os Alvarás de Localização e Funcionamento e autorizações emitidos para todas as atividades comerciais e dá outras providências" (BELO HORIZONTE, 8 de abril de 2020).

\section{Decreto $n^{0}$ 17.332, de 16 de Abril de 2020}

“Torna obrigatório o uso de máscaras, restringe o acesso de clientes em estabelecimentos comerciais durante a Situação de Emergência em Saúde Pública no Município e dá outras providências" (BELO HORIZONTE, 16 de abril de 2020).

\section{Decreto n⿳ 17.333, de 16 de Abril de 2020}

"Dispõe sobre medidas de contingenciamento orçamentário e financeiro no âmbito do Poder Executivo" (BELO HORIZONTE, 16 de abril de 2020).

\section{Decreto $\mathrm{n}^{\circ}$ 17.334, de 20 de Abril de 2020}

"Declara estado de calamidade pública no Município de Belo Horizonte, em razão da necessidade de ações para conter a propagação de infecção viral, bem como de preservar a saúde da população contra o Coronavírus - COVID-19” (BELO HORIZONTE, 20 de abril de 2020). 
Todos os decretos supracitados são direcionados para uma cidade fechada e como proteger os cidadãos do contágio, de modo a prevenir e incentivar o distanciamento social, ampliando sempre a taxa que tem como ideal estar em torno dos $50 \%$.

Os próximos decretos já apresentam um direcionamento para o início da flexibilização do distanciamento social e reabertura gradual da cidade.

\section{Decreto n' 17.348, de 27 de Abril de 2020}

"Institui grupo de trabalho para avaliar e planejar a reabertura gradual e segura dos setores que tiveram as atividades suspensas em decorrência das medidas para enfrentamento da epidemia causada pelo Coronavírus e para propor critérios de isolamento intermitente” (BELO HORIZONTE, 27 de abril de 2020).

\section{Decreto $\mathrm{n}^{0}$ 17.356, de 14 de Maio de 2020}

“Dispõe sobre a instalação de pontos de fiscalização sanitária para evitar a propagação de infecção viral e preservar a saúde da população contra a doença provocada pelo Novo Coronavírus - Covid-19 - e dá outras providências" (BELO HORIZONTE, 14 de maio de 2020).

\section{Decreto $n^{0}$ 17.361, de 22 de Maio de 2020}

"Dispõe sobre a reabertura gradual e segura dos setores que tiveram as atividades suspensas em decorrência das medidas para enfrentamento e prevenção à epidemia causada pelo novo Coronavírus"' (BELO HORIZONTE, 22 de maio de 2020).

\section{Decreto $\mathrm{n}^{\circ} \mathbf{1 7 . 3 6 2}$, de 22 de Maio de 2020}

"Dispõe sobre medidas voltadas à prevenção da disseminação da epidemia de Covid - 19 no serviço público de transporte coletivo de passageiros por ônibus do Município", (BELO HORIZONTE, 22 de maio de 2020). 


\section{Decreto n⿳ 17.377, de 26 de Junho de 2020}

"Suspende, por prazo indeterminado, as fases 1 e 2 do Anexo II do Decreto $n^{\circ} 17.361$, de 22 de maio de 2020, e dá outras providências" (BELO HORIZONTE, 26 de junho de 2020).

A cidade de BH teve o início da flexibilização gradual determinada pelo decreto 17.361, com um plano de reabertura e reavaliação dos impactos decorrentes da mesma, entretanto, na segunda fase de flexibilização, notou-se um aumento significativo nos casos de covid-19, além de um aumento expressivo na ocupação dos leitos hospitalares, gerando uma preocupação com o estrangulamento do sistema público e privado de saúde. Deste modo, a cidade voltou a ser fechada, os casos dispararam, mas mesmo assim podese perceber que a taxa de distanciamento social diminuiu, mesmo com os alertas do comitê de saúde.

\section{Impactos dos Decretos da PBH no Lazer dos Belo-Horizontinos}

Desde o primeiro Decreto assinado pelo Prefeito de Belo Horizonte, Alexandre Kalil, no dia 17 de março de 2020, parques, clubes, quadras de futebol Society, praças, bares, shoppings, dentre outros locais disponíveis para as práticas de lazer da população tiveram o seu funcionamento impedido, com a finalidade de conter a propagação da Covid-19. Durante esse período de distanciamento social que a população vem enfrentando, destacamos dois Decretos datados de 27 de abril e 22 de maio de 2020, respectivamente, que tiveram como finalidade organizar e efetuar uma abertura gradual de pontos de comércio da cidade, devido a pressão exercida por alguns setores da sociedade, como comerciantes, trabalhadores autônomos e empreendedores.

No entanto, o que se observa é que mesmo nesses Decretos em que foi discutido um afrouxamento do distanciamento social, os espaços de lazer não foram pautas das 
resoluções da $\mathrm{PBH}$ e permaneceram fechados. Podemos entender, que as autoridades responsáveis pelo combate à pandemia e os órgãos de saúde, compreendem que os espaços de lazer possuem um elevado potencial de aglomeração e, por consequência de disseminação do vírus da Covid-19.

De acordo com reportagem do jornal Estado de Minas ${ }^{15}$, uma pesquisa realizada por estudantes da PUC ${ }^{16}$ Paraná, aponta Belo Horizonte como a segunda capital brasileira mais amigável para a prática de exercícios físicos, ficando atrás somente de Florianópolis. O estudo utilizou como critérios de classificação: o acesso a espaços de lazer; o acesso ao transporte público; o desenho urbano; a estrutura viária para atividade física; o trânsito e a criminalidade. Através dessa reportagem, podemos perceber o quão grande está sendo o impacto para a população belo-horizontina dos espaços de lazer fechados por tempo indeterminado. Ressaltamos que essa concussão não foi apenas econômica e estrutural, mas atingiu as pessoas, diretamente, visto que com o distanciamento social elas tiveram a sua liberdade de certa maneira impedida. Já que elas não têm acesso aos mesmos equipamentos de lazer, como tinham em tempos anteriores à pandemia.

Para Dumazedier (1976, 1979) o lazer possui conteúdos culturais, classificados em cinco componentes: físicos, artísticos, manuais/práticos, intelectuais e sociais. Para além dessa categorização, Camargo (1980) adicionou os interesses turísticos e Schwartz (2003) acrescentou os interesses virtuais, como pertencentes aos conteúdos culturais do lazer. Dessa forma, podemos pensar, em tempos de distanciamento social, a importância e a maior influência do conteúdo virtual em detrimento a outros conteúdos do lazer, como o turístico, pois uma parcela da população belo-horizontina se encontra no ambiente doméstico e as viagens estão suspensas devido à Covid-19.

\footnotetext{
15 Disponível em: https:/www.em.com.br/app/noticia/gerais/2018/10/07/interna_gerais,994887/bh-e-a-2capital-do-pais-com-mais-qualidades-para-praticar-esportes.shtml. Acesso em: 11 jul. 2020 às 13:10.

${ }^{16}$ A sigla PUC significa: Pontifícia Universidade Católica.
}

licere, Belo Horizonte, v.23, n.3, set/2020. 
O Brasil, no entanto, se caracteriza por um país com ofertas de direitos sociais desiguais, como: educação, saúde e lazer. Fato que evidencia problemas sociais cotidianos e que em períodos de situações ímpares, como o que estamos vivendo, mostra a incapacidade do Estado Brasileiro de arcar com um auxílio integral e digno para as famílias que estão em situação de vulnerabilidade social e que não possuem condições estruturais para arcarem com atividades de lazer dentro do próprio ambiente doméstico.

Por isso, o lazer em tempos de pandemia e distanciamento social apresenta características de exclusão mais evidentes. Isso se deve ao fato de que os equipamentos de lazer gratuitos, fornecidos para a população estarem fechados por período indeterminado, sendo o fenômeno do lazer estendido somente para o ambiente doméstico, limitando-se à televisão, ao computador e à criatividade de cada família em suas residências. Há poucas pessoas que tem acesso a casas equipadas com quadras e piscinas, por exemplo, o que permite com que apenas essa parte reduzida da população de Belo Horizonte consiga ter acesso à uma forma de lazer menos distante daquelas, geralmente praticadas.

Nesse período de pandemia, as lives também se tornaram opções de lazer, contudo, as famílias que possuem acesso a esses shows gratuitos, são aquelas que têm acesso à internet em casa. A programação televisiva também mudou. Um exemplo é o futebol, visto que os jogos de quarta-feira à noite e aos domingos às $16 \mathrm{~h}$ não estão acontecendo, a emissora detentora dos direitos de transmissão de grande parte dos clubes brasileiros, passou durante quatro semanas do distanciamento social reprises de jogos históricos.

Também é importante dizer, que a prática de exercícios físicos foi restringida para o espaço doméstico, o que em muitos casos gera uma limitação das atividades, 
Os Impactos Causados pelos Decretos da Prefeitura de Belo Horizonte no Lazer da População Ana Cláudia Porfírio Couto; Fábio Henrique França Rezende e Aládia Cristina Rodrigues Medina

costumeiramente realizadas em espaços próprios, como academias de musculação. As fotos abaixo mostram espaços público da cidade que não estão "em funcionamento".

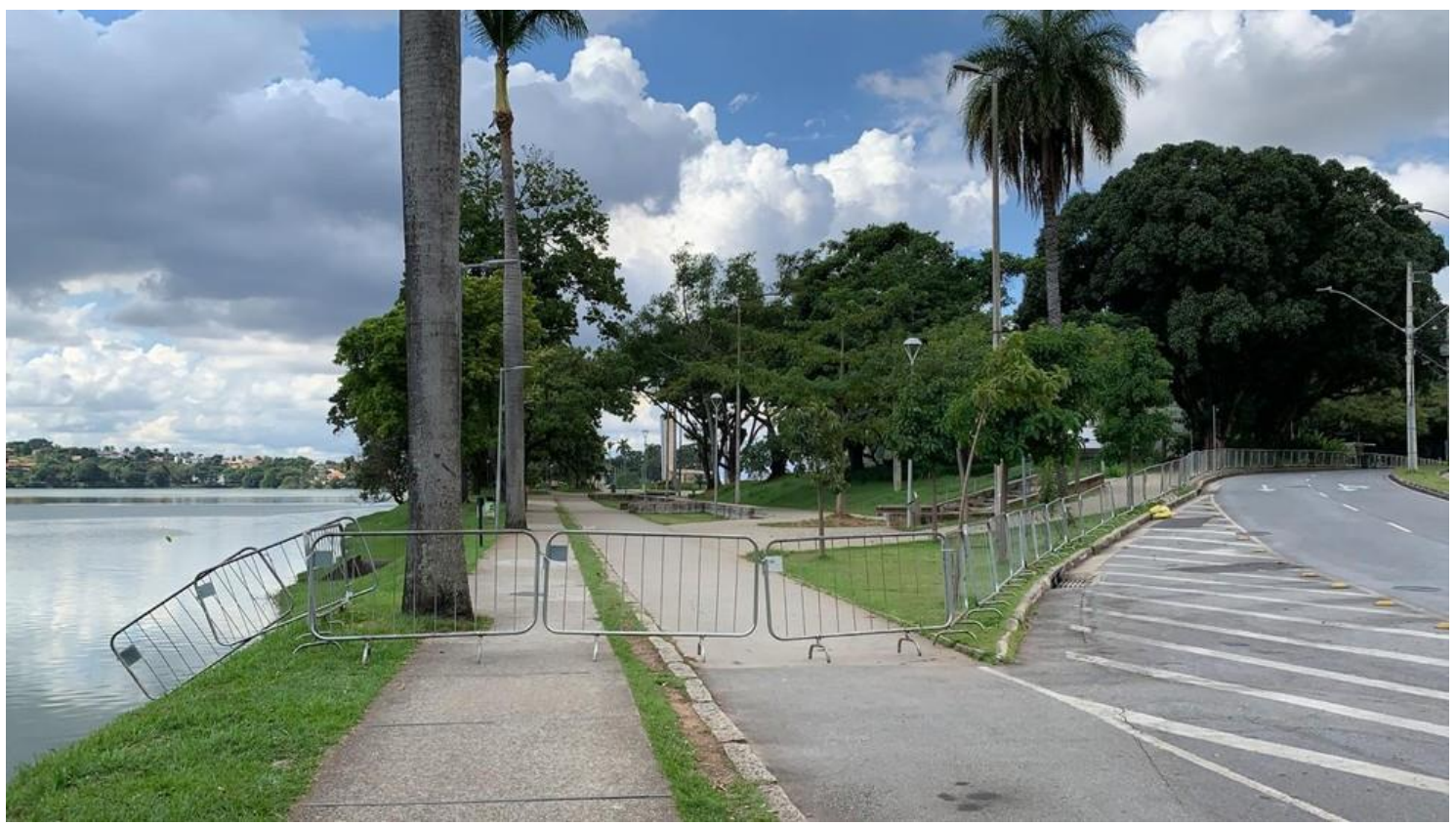

Foto: Fechamento da Lagoa da Pampulha/ G1. globo.com 08-04-2020.

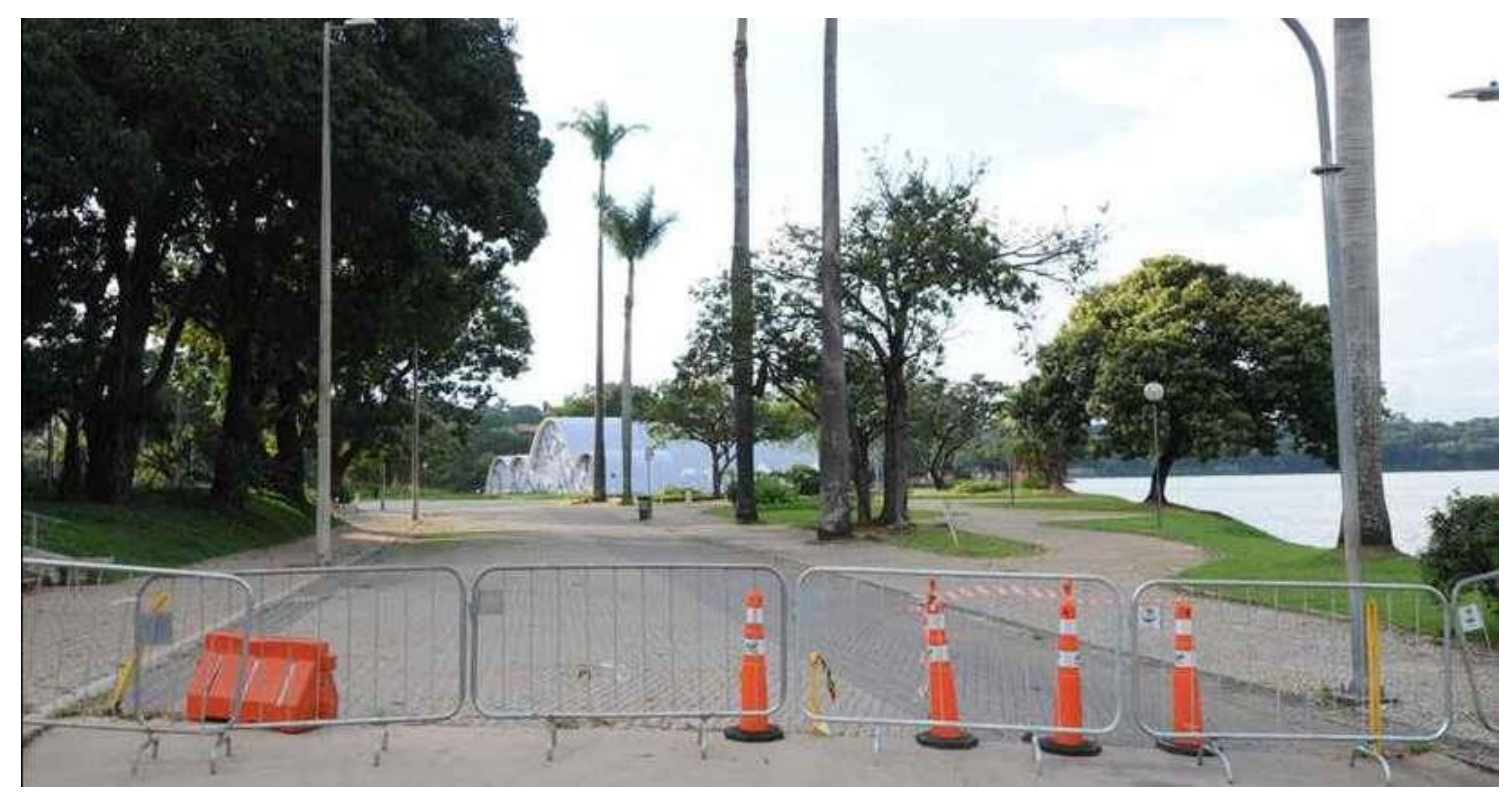

Foto: Juarez Rodrigues/EDM/DA ESTADO DE MINAS GERAIS 09-04-2020

licere, Belo Horizonte, v.23, n.3, set/2020. 
Entretanto, em Belo Horizonte e em outras cidades brasileiras, observa-se que as pessoas estão "furando" a sugestão dos governos e dos órgãos de saúde, em relação ao distanciamento social, para a realização de exercícios físicos ao ar livre, o que tem gerado aglomerações em alguns pontos da cidade. O portal $\mathrm{O}$ Tempo $^{17}$ mostra em uma reportagem que tanto na Lagoa Seca, localizada no bairro Belvedere na regional CentroSul de Belo Horizonte, como Lagoa da Pampulha, localizada no bairro São Luiz na regional da Pampulha, a população ignorou a recomendação de distanciamento social feita pela PBH e aproveitou o domingo, nesses dois pontos de lazer da cidade.

A discussão a respeito da realização de exercícios físicos ao ar livre, mesmo com máscara, movimentou a mídia mineira e nacional, visto que esse fato vem ocorrendo em diversos locais do Brasil. De acordo com a BBC News Brasil de São Paulo ${ }^{18}$, a prática de exercícios físicos ao ar livre, mesmo em época de isolamento, pode ser benéfica para a saúde física e mental das pessoas, desde que respeitadas todas as normas de segurança da OMS, como: uso de máscara; se manter a uma distância de um a dois metros de outras pessoas; lavar as mãos com sabonete antes de sair de casa e ao chegar em casa; utilizar álcool gel antes e após o exercício e evitar tocar em superfícies que possam estar contaminadas com o vírus, como corrimões, escadas, maçanetas, etc. Além disso, esse mesmo periódico, afirma que a Sociedade Brasileira de Medicina do Exercício e do Esporte (SBMEE) em uma manifestação sobre o assunto, no dia 30 de março de 2020, recomenda a prática de exercícios ao ar livre, exceto quando se estes forem proibidos, por meio de Decreto de Lei do Poder Executivo.

\footnotetext{
17 Disponível em: https://www.otempo.com.br/cidades/lagoa-seca-e-orla-da-pampulha-tem-domingomovimentado-em-meio-a-pandemia-1.2321079. Acesso em: 13 jul. 2020 às 10:22.

${ }^{18}$ Disponível em: https://www.bbc.com/portuguese/geral-52170288. Acesso em: 26 jul. 2020 às 20:10.
} 


\section{Considerações Finais}

Em síntese, o estudo em questão teve como finalidade investigar o impacto das medidas adotadas pela PBH nas práticas de lazer dos belo-horizontinos durante a pandemia da Covid-19. Para tanto, este estudo se desdobrou em dois momentos específicos, analisar as medidas impostas pela $\mathrm{PBH}$ e relacionar os espaços de lazer e os consequentes impactos no lazer da população, a fim de estabelecer um diálogo diante da problemática do estudo.

Dessa forma, o lazer da população desde o primeiro Decreto assinado pelo Prefeito de Belo Horizonte, Alexandre Kalil no dia 17 de março, passou a se restringir para o ambiente doméstico. As pessoas tiveram que reorganizar suas atividades, de modo a realizarem atividades de divertimento, prática de exercícios físicos, trabalhos, estudos, acompanhar shows e de descanso, exclusivamente em casa. Isso trouxe uma nova dinâmica para a vida da população mundial, que precisou reinventar e reorganizar suas vivências de lazer.

O distanciamento social vem exigindo um autoconhecimento e uma capacidade de lidar com a solidão insigne, visto que problemas que antes eram resolvidos com uma ida ao bar com os amigos ou com um passeio ao shopping, devem ser resolvidos no próprio espaço domiciliar, por meio de encontros por aplicativos de conversas, por exemplo. Logo, a ideia de Marcelino (2008) que trata o lazer, como uma cultura vivenciada no tempo disponível das obrigações, se mistura com as atividades laborais realizadas no espaço doméstico durante o período de distanciamento social.

Portanto, podemos entender essas práticas de lazer, assim como aulas e atividades laborais no ambiente doméstico, como o "novo normal”. Essa denominação irá fazer parte do cotidiano das pessoas por algum tempo, que no momento os órgãos de saúde não conseguem estipular, visto o alastramento mundial que a Covid-19 tomou em alguns 
meses. Entretanto, é interessante refletir e nos questionarmos sobre a mudança ocorrida no mundo, o fato de que as pessoas mudaram durante essa crise global, que as medidas de segurança devem tornar-se hábitos e que o futuro em diferentes áreas da sociedade é algo incerto. Porém, a união das pessoas para a formação de um mundo mais igual e seguro, deve ser trabalhada por educadores, governantes, pela mídia e pelas próprias pessoas, com a finalidade de em um cenário pós - pandemia as relações humanas e os detalhes antes considerados sem importância podem passar a valer mais do que outros valores antes colocados em pauta, como status social e capital financeiro.

Em suma, o vírus continuará presente na vida das pessoas, mesmo após a criação de uma vacina a nível mundial e isso impacta, diretamente nas atividades de lazer que estamos acostumados a praticar. Abraços, apertos de mãos, compartilhamento de objetos, por exemplo, não serão mais vistos como situações inocentes e de descontração. As práticas de lazer foram e ainda serão por muito tempo direta e indiretamente impactadas pelos decretos decorrentes da pandemia da covid-19, visto que a população passou a viver a vida em outra "normalidade", com o uso de espaços totalmente ressignificados, quer seja para o trabalho, para o lazer, para a prática de esportes, ou seja, para se viver.

Percebemos que o impacto foi também marcado pelo poder econômico, o status social impôs determinados modos de vida durante o distanciamento social, pois como foi dito, o privilégio de espaços de lazer nas residências, acesso à internet, tv paga etc. não é de toda a população, assim, o não uso do espaço público demarca mais uma vez a desigualdade social do antes e durante pandemia no Brasil e que o mundo verá ainda mais discrepante no período pós pandemia.

licere, Belo Horizonte, v.23, n.3, set/2020. 


\section{REFERÊNCIAS}

BBC NEWS BRASIL: Coronavírus: fazer exercícios físicos ao ar livre durante a quarentena é recomendável? Disponível em: https://www.bbc.com/portuguese/geral52170288. Acesso em: 26 jun. 2020.

BELO HORIZONTE. Prefeitura de Belo Horizonte - Fundação de parques e Zoobotânica - Parques: Como parte dos esforços de contenção ao COVID-19 (Coronavirus), a Fundação de parques e Zoobotânica informa o fechamento temporário de todas as suas unidades (Parques, Jardim Zoológico, Jardim Botânico e centros de Vivência Agroecologia). Disponível em: https://prefeitura.pbh.gov.br/fundacao-de-parques-ezoobotanica/parques. Acesso em: 1 jul 2020.

BELO HORIZONTE, Diário Oficial do município. Decreto n. 17.297 de 17 de março de 2020. Ano XXVI-Edição N.: 5976-EXTRA. Disponível em: http://portal6.pbh.gov.br/dom/iniciaEdicao.do?method=DetalheArtigo\&pk=1226967. Acesso em: 29 jun. 2020.

Decreto n. 17.298 de 17 de março de 2020. Ano XXVI - Edição N.: 5976 EXTRA.

Disponível em: https://portal6.pbh.gov.br/dom/iniciaEdicao.do?method=DetalheArtigo\&pk=1226966. Acesso em: 29 jun. 2020.

Decreto n. 17.304, 18 de março de 2020. Ano XXVI-Edição N.: 5977-EXTRA. Disponível em: http://portal6.pbh.gov.br/dom/iniciaEdicao.do?method=DetalheArtigo\&pk=1227069. Acesso em: 29 jun. 2020.

Decreto n. 17.308, 19 de março de 2020. Ano XXVI-Edição N.: 5978 - EXTRA. Disponível em: http://portal6.pbh.gov.br/dom/iniciaEdicao.do?method=DetalheArtigo\&pk=1227166. Acesso em: 29 jun. 2020. EXTRA.

Decreto n.17.309, 19 de março de 2020. Ano XXVI - Edição N.: 5978 http://portal6.pbh.gov.br/dom/iniciaEdicao.do?method=DetalheArtigo\&pk=1227166\#: :text=DECRETO\%20N\%C2\%BA\%2017.308\%2C\%20DE\%2019,pandemia\%20ocasion ada\%20pelo\%20COVID\%2D19.

Disponível

Decreto n. 17.313, 21 de março de 2020. Ano XXVI-Edição N.: 5980 - EXTRA. http://portal6.pbh.gov.br/dom/iniciaEdicao.do?method=DetalheArtigo\&pk=1227225. Acesso em: 29 jun. 2020.

Decreto n. 17. 319, quinta - Feira, 2 de abril de 2020. Disponível em: https://www.legisweb.com.br/legislacao/?id=392276. Acesso em: 29 jun. 2020.

Disponível

Decreto n. 17.326, terça - feira, 7 de abril de 2020. Ano XXVI-Edição N.: 5991. http://portal6.pbh.gov.br/dom/iniciaEdicao.do?method=DetalheArtigo\&pk=1227679. Acesso em: 29 jun. 2020. 
BELO HORIZONTE, Diário Oficial do município. Decreto n. 17.328, 8 de abril de 2020. Ano XXVI-Edição N.: 5992 - EXTRA. Disponível em: http://portal6.pbh.gov.br/dom/iniciaEdicao.do?method=DetalheArtigo\&pk=1227725 . Acesso em: 29 jun. 2020.

5898.

Decreto n. 17.332, sexta - feira, 17 de abril de 2020. Ano XXVI-Edição N.: http://portal6.pbh.gov.br/dom/iniciaEdicao.do?method=DetalheArtigo\&pk=1227955 Acesso em: 1 jul. 2020.

5898.

Decreto n. 17.333. Sexta - Feira, 17 de abril de 2020. Ano XXVI-Edição N.:

em: https://portal6 pbh gov br/dom/iniciaEdicao.do?method=DetalheArtigo\&pk=12279

55. Acesso em: 1 jul. 2020.

Decreto n. 17. 334, terça - feira, 21 de abril de 2020. Disponível em: https://www.legisweb.com.br/legislacao/?id=393313 . Acesso em: 1 jul. 2020.

Disponível

Decreto n. 17.348, terça - feira, 28 de abril de 2020. Ano XXVI-Edição N.: 6004. http://portal6.pbh.gov.br/dom/iniciaEdicao.do?method=DetalheArtigo\&pk=1228233 Acesso em: 1 jul. 2020.

Decreto n. 17.356, Sexta - Feira, 15 de maio de 2020. Disponível em: https://www.legisweb.com.br/legislacao/?id=395458 . Acesso em: 1 jul. 2020.

Decreto n. 17.361, 22 de maio de 2020. Ano XXVI-Edição N.: 6021 - EXTRA. Disponível em: http://portal6.pbh.gov.br/dom/iniciaEdicao.do?method=DetalheArtigo\&pk=1229012 . Acesso em: 3 jul. 2020.

Decreto n. 17.362, Sábado, 23 de maio de 2020. Disponível em: https://www.legisweb.com.br/legislacao/?id=395936. Acesso em: 3 jul. 2020.

Decreto n. 17.377, Sábado, 27 de junho de 2020. Disponível em: https://www.legisweb.com.br/legislacao/?id=397679 . Acesso em: 3 jul. 2020.

BRASIL. Constituição da República Federativa do Brasil: promulgada em 5 de outubro de $1988 . \quad$ Disponível em: http://www.planalto.gov.br/ccivil_03/constituicao/constituicao.htm. Acesso em: 30 jun. 2020.

CAMARGO, L.O.L. O que é lazer? São Paulo: Brasiliense, 1980.

DUMAZEDIER, J. Lazer e cultura popular. São Paulo: Perspectiva, 1976.

Sociologia empírica do lazer. São Paulo: Perspectiva, 1979.

ESTADO DE MINAS: Contra coronavírus, prefeitura começa a bloquear orla da Pampulha. Disponível em: https://www.em.com.br/app/galeriadefotos/2020/04/08/interna_galeriafotos, 7154/contra-coronavirus-prefeitura-comeca-abloquear-orla-da-pampulha.shtml. Acesso em: 10 jul. 2020.

licere, Belo Horizonte, v.23, n.3, set/2020. 
ESTADO DE MINAS GERAIS: Belo Horizonte é a segunda capital do país com mais qualidades para quem pratica esportes. Disponível em: https://www.em.com.br/app/noticia/gerais/2018/10/07/interna_gerais,994887/bh-e-a-2capital-do-pais-com-mais-qualidades-para-praticar-esportes.shtml. Acesso em: 11 jul. 2020.

G1 MINAS - BELO HORIZONTE: Coronavírus: Prefeitura começa a interditar pontos da orla da Lagoa da Pampulha, em BH. Disponível em: https://g1.globo.com/mg/minasgerais/noticia/2020/04/08/coronavirus-prefeitura-comeca-a-isolar-pontos-da-orla-dalagoa-da-pampulha-em-bh.ghtml. Acesso em: 16 jul. 2020.

GEERTZ, Clifford. A interpretação das culturas. Rio de Janeiro: LTC, 2008.

GOMES, Christianne Luce (Org.). Dicionário crítico do lazer. Belo Horizonte: Autêntica Editora, 2004.

Recreação e lazer: apontamentos históricos no contexto da educação física. In: GOMES, Christianne Luce. ISAYAMA, Hélder Ferreira. (Orgs.) Lazer, recreação e educação física. Belo Horizonte: Autêntica, 2003.

Lazer: necessidade humana e dimensão da cultura. Revista Brasileira de Estudos do Lazer. Belo Horizonte, v.1, n.1, p. 3-20, jan-abr 2014.

GOMES, Cristina Marques. Dumazedier e os estudos de lazer no Brasil: breve trajetória histórica. Disponível em: https://ufrj.edu.br:/portal-repositorio:/file:/dcefs Acesso em: 02 ago. 2018.

HISTÓRIA do MUNDO: Cinco doenças que marcaram a história da humanidade. Disponível em: https://www.historiadomundo.com.br/curiosidades/cinco-doencas-quemarcaram-a-historia-da-humanidade.htm. Acesso em: 1 jul. 2020.

JORNAL DA USP: Covid tem gênero? Disponível em: https://jornal.usp.br/artigos/covid-tem-genero/. Acesso em: 11 jul. 2020.

JORNAL O TEMPO: Lagoa Seca e orla da Pampulha têm domingo movimentado em meio à pandemia. Disponível em: https://www.otempo.com.br/cidades/lagoa-seca-eorla-da-pampulha-tem-domingo-movimentado-em-meio-a-pandemia-1.2321079.

Acesso em: 13 jul. 2020.

MARCELliNO, Nelson Carvalho. Estudos do lazer: Uma introdução. Campinas. Autores Associados, 1998.

O lazer e os espaços na cidade. In.: ISAYAMA, Hélder, LINHALES, Meily Assbú (Orgs.). Sobre lazer e política: maneiras de ver maneiras de fazer. Belo Horizonte: Editora UFMG, 2006.

Lazer e Sociedade: Múltiplos Olhares. Campinas: Editora Alínea, 2008

RODRIGUES, Rejane Pena. Programa Esporte e lazer da cidade. Brincar, jogar, viver. Ministério do Esporte. Programa Esporte e Lazer da Cidade, v.1, n. 01, Janeiro/2007. 
SCHWARTZ, G.M. O conteúdo virtual: contemporizando Dumazedier. Licere, Belo Horizonte: UFMG, v. 2, n. 6, p. 23-31, 2003.

SILVA, Daniel Neves Silva. Cinco doenças que marcaram a história da humanidade. Disponível em: http://www.historiadomundo.com.br/curiosidades/cinco-doencas-quemarcaram-a-historia-da-humanidade.htm. Acesso em: 11 jul. 2020.

UOL: Estudo aponta relação de $\mathbf{9 6 , 2 \%}$ entre novo coronavírus e morcego-ferradura. Disponível em: https://noticias.uol.com.br/ultimas-noticias/agenciaestado/2020/06/05/estudo-aponta-relacao-de-962-entre-novo-coronavirus-e-morcegoferradura.htm. Acesso em: 03 jul. 2020.

UOL: O que é pandemia e o que muda após declaração da OMS sobre o novo coronavírus. Disponível em: https://noticias.uol.com.br/ultimasnoticias/bbc/2020/03/11/o-que-e-pandemia-e-o-que-muda-apos-declaracao-da-omssobre-o-novo-coronavirus.htm. Acesso em: 01 jul. 2020.

VEJA SAÚDE: Coronavírus: como a pandemia nasceu de uma zoonose. Disponível em: https://saude.abril.com.br/medicina/coronavirus-pandemia-zoonose/. Acesso em: 1 jul. 2020.

ZINGONI, Patrícia. Descentralização e participação em gestões municipais de esporte e lazer. In: GOMES, Christianne Luce; ISAYAMA, Hélder Ferreira. (Orgs.) Lazer, recreação e educação física. Belo Horizonte: Autêntica, 2003.

\section{Endereço dos/as Autores/as:}

Ana Cláudia Porfírio Couto

EEFFTO/UFMG

Av. Antônio Carlos, 6627

Belo Horizonte - MG - 31270-901

Endereço eletrônico: acpcouto@gmail.com

Fábio Henrique França Rezende

EEFFTO/UFMG

Av. Antônio Carlos, 6627

Belo Horizonte - MG - 31270-901

Endereço eletrônico: fabiohrezende94@gmail.com

Aládia Cristina Rodrigues Medina

Al. Carlos Drumond de Andrade 309, Quintas II

Nova Lima - MG - 34.003-318

Endereço eletrônico: aladiamedina34@gmail.com 